\title{
INVESTIGATION OF CRIMES AGAINST FAMILY MEMBERS
}

\author{
E.-A. Nechita, N. Iancu
}

\section{Elena-Ana Nechita}

Law and Economics Faculty, Social Sciences Department

Agora University of Oradea, Oradea, Romania

*Correspondence: Elena-Ana Nechita, Agora University of Oradea, 8 Piaţa Tineretului St., Oradea, Romania

E-mail: departament@univagora.ro anaelena2009@yahoo.com

\section{Nicolaie Iancu}

Law and Economics Faculty, Social Sciences Department

Agora University of Oradea, Oradea, Romania

*Correspondence: Nicolaie Iancu, Agora University of Oradea, 8 Piaţa Tineretului St., Oradea, Romania

E-mail niancu2009@yahoo.com

\section{Abstract}

The authors intended the first part of the article to present considerations on the moral and legal rules that provide for the rights and obligations of participants in family relationships. An analysis of acts constituting offences in light of the New Romanian Criminal Code will be provided.

Part two will include the presentation of activities specific to criminal investigations where acts are committed that meet the elements of offences against the family, activities such as: the crime scene investigation, the hearing of people with different standings in the case, forensic and psychiatric expertises, reconstructions, searches.

Keywords: investigation, forensic science, family, crime

\section{Introduction}

Given the fact that violence in general is on the rise in society and that the Romanian legislation on domestic violence either has recently changed through Law No. 217/2003 on preventing and combating domestic violence, republished in the Official Journal of Romania No. 365/2012, or will change through the new Romanian Criminal Code, Law No. 286/2009 published in the Official Journal of Romania, Part I, No. 510/2009, at the date of its entry into force (probably 1st of February, 2014, according to Law No. 187/2012 for the implementation of Law No. 286/2009 regarding the Criminal Code, published in the Official Journal No. 757/November 2012), we consider it useful to approach this topic.

The usefulness of the subject also lies in the role, demonstrated and supported by scientific theories that the family, as a primary social group, exerts on the child's personality and behaviour. In addition to the fact that the violence manifested in the family of origin spoils the family environment, it increases the chances for children to reiterate the social role models provided by their parents ${ }^{1}$.

The parallel presentation of the current Romanian legislation and of the new legislative bills has scientific relevance among specialists from the country, as well as from

\footnotetext{
${ }^{1}$ Onica-Chipea, L., Aspecte socio-juridice privind protecția drepturilor copilului. Studiu de caz în județul Bihor (Socio-Legal Issues of Children's Rights Protection. A Case Study in Bihor County), Expert Publishing House, Bucharest, 2007, pp. 27-28, pp. 230-238.
} 
abroad, because they can thus become familiar with or gather documentation regarding: certain terms (family member), the basic concepts in this area (domestic violence), the offences provided for under the Romanian Criminal Code, peculiarities of forensic science investigation.

The complexity of the forensic investigation and the peculiarities of the activities carried out in order to establish the truth in a case, to demonstrate the constituent elements of offences which lie in the use of violence, are also due to the specificity of the relations between the participants.

Violence is one of the major problems of the contemporary world. The media constantly inform us about various manifestations of this phenomenon, from its most aggressive forms such as wars or crimes of homicide, assault, rape, theft, destruction of property, to the less shocking ones, such as verbal violence ${ }^{2}$.

Also, the topicality of the subject presented here is given by the fact that domestic violence occurs in all social and cultural backgrounds, in various ways, among people whose relationships are generally based on friendship, fondness, mutual moral and material support. Moreover, globalization, whose effects we have witnessed in the past few decades, has an impact even on social structures, such as the family ${ }^{3}$.

Migration for family reasons, with its two main forms4: family formation and family reunification, can lead to the formation of environments with a vulnerability risk for the occurrence of domestic abuse, whether we think of the family members left behind, or of those who have left.

As a result, there are many situations where these facts fall within the category of things that go unnoticed, and, when they do get to be known by non-governmental organizations or institutions charged with their investigation, assistance or counselling, problems often occur in practice, because of the holding back and fears of the categories of people involved.

In its general sense, domestic violence is any act that is physically or emotionally injurious and occurring between family members.

The Romanian Criminal Code in force at the time of writing the article, defines a family member, in Article $149^{\wedge} 1$, as "the spouse or close relative, if the latter lives and shares the household with the perpetrator".

According to Article 149 of the Criminal Code, close relatives are "the ascendants and descendants, brothers and sisters, their children, as well as people who have become such relatives by adoption, in compliance with the law...". members as:

The New Romanian Criminal Code, in Article 177, paragraph 1, defines family

a) the ascendants and descendants, brothers and sisters, their children, as well as people who have become such relatives by adoption, in compliance with the law;

b) the spouse;

c) persons who have established relationships similar to those between spouses or between parents and children, if they live together.

According to paragraph 2, the criminal law provisions regarding family members, "shall also apply, within the limitations provided for in para. (1), letter a), in the case of adoption, to the adopted person or his/her descendants in relation to the natural relatives".

\footnotetext{
2 Nicoleta-Elena Buzatu, Illicit Consumption of Narcotics - Violence Generator, vol. MEDIMOND, International Proceedings Medimond - Monduzzi Editore International Proceedings, Division, Publishing House Editografica, Bologna, Italy, 2012, p. 221.

${ }^{3}$ Viorica Banciu, Angela Jireghie, Delia Ştefania Florian, Multiculturalism and Metissage in the Globalization Context, Tudományos és kulturális folyóirat, published by Szent István Egyetem Gazdasági, Agrár- és Egészségtudományi Kar Békéscsaba, 2012, no. 18, p. 80, gfk.tsf.hu/docs/system/files/files/pers2012_xvi_18.pdf ${ }^{4}$ Nicolaie Iancu, Migrația internațională a forței de muncă (International Labour Migration), Pro Universitaria Publishing House, Bucharest, 2010, p. 96.
} 
Law No. 217/2003 on preventing and combating domestic violence, republished, extends the notion of the family member in Article 5. Thus, at letter b), we notice that beside the husband/wife, the former husband/former wife is mentioned; at letter d), the guardian or another person who exercises by law or in fact his/her rights regarding the child, and at letter e), the legal representative or caregiver of a person with a mental illness, intellectual disability or physical handicap, except those who fulfill these responsibilities in the exercise of their professional duties.

We note, in particular, the legislator's concern for persons who, without having welldefined capacities, need protection from possible abuse, namely "persons who have established relationships similar to those between spouses or between parents and children, if they live together" or "the former husband/former wife", in compliance with the law on preventing and combating domestic violence.

Law No. 217/2003 also defines domestic violence in Article 3, stating that it means "any intentional act or omission, except for self-defense or defense actions, manifested physically or verbally, committed by a family member against another member of the same family, which causes or may cause an injury or physical, mental, sexual, emotional or psychological suffering, including threats of such acts, coercion or arbitrary deprivation of liberty". Preventing women from exercising their fundamental rights and freedoms also constitutes domestic violence.

Broadly speaking, a family is a social group whose members are bound by relationships of age, marriage or adoption and who live together, cooperate in economic matters and have children in their care ${ }^{5}$.

In the criminal doctrine, the term "minor" from civil law has always been used in reference to children and adolescents, since 1938. After 1990, under the influence of international documents, the Romanian legislation has also been using the notion of "child", as synonymous with that of "minor", giving priority to the sociological meaning of the concept, as compared to the legal one ${ }^{6}$.

Aspects of criminal law relating to offences against the family members. Comparison between the Romanian Criminal Code and the proposals contained in the new Criminal Code

Title IX, Offences Against Relationships Regarding Social Cohabitation, Chapter I, Offences Against the Family, of the Romanian Criminal Code (in force at the time of writing this article), includes offences that have as a legal object: social relationships regarding social cohabitation within the family, social relationships that prevent the fulfillment of the legal obligation to support the person entitled to maintenance, social relationships that involve caring for the physical, mental, intellectual and moral development of the minor.

In the new Romanian Criminal Code, crimes against the family are provided for in Title VIII, Chapter II, Art. 376-380. The novelty it brings about is the criminalization of a new fact, namely the offence of obstruction of access to general compulsory education, under Art. 380 .

We also notice a regrouping of the offences mentioned in this chapter, namely: the relocation of the offence of ill treatment of a minor provided for in Art. 306 Criminal Code in force to another chapter of the new Criminal Code. Also, the offence of incest, provided for in Title II Offences Against the Person, Chapter III Offences Regarding Sexual Life, Art. 203 of

\footnotetext{
${ }^{5}$ Cornelia Rada, Repere antropologice ale familiei în contextul sănătății sexual-reproductive (Anthropological Landmarks of the Family in the Context of Sexual and Reproductive Health), "Academiei Române" Publishing House, Bucharest, 2009, p. 40.

${ }^{6}$ Nicoleta-Elena Buzatu, The Minor - The Active Subject of a Crime, vol. MEDIMOND, International Proceedings Medimond - Monduzzi Editore International Proceedings, Division, Editura Editografica, Bologna, Italy, 2012, p. 226; For the regulations on minority contained in the new Criminal Code, see Nicoleta-Elena Buzatu, Regulations Concerning the Minors as Stipulated in The New Penal Code, in Vol. „Criza actuală în contextul globalizării" ("The Current Crisis in the Context of Globalization"), Pro Universitaria Publishing House, Bucharest, 2010, pp. 837-839.
} 
the Romanian Criminal Code, is relocated to the same chapter of the new Criminal Code, Art. 377.

The legal content of the offence of incest provided for in the two codes is different in terms of the penalty, in the sense that the new Criminal Code provides for a lesser penalty (imprisonment from one year to 5 years) as compared to the code currently in force (imprisonment from 2 to 7 years). Also, the content of the offence in the new Criminal Code highlights the lawmaker's concern to be explicit as regards the subjective side, i.e. sexual intercourse between relatives in direct line, between brothers and sisters which is committed with consent.

The criminal offence of bigamy is provided for in Article 303 of the Romanian Criminal Code, having as the material element of its objective side the action of "entering into a new marriage while still married to another" in the wording of para. 1, or an unmarried person's action of "marrying a person whom one knows to already be married" in the wording of para. 2.

We note that bigamy is also provided for in the new Criminal Code in Art. 376, having the same material element of its objective side. In this case too, penalties are different in that they are lower in the new Criminal Code. In the wording of para. 1, the penalty is imprisonment from 3 months to 2 years or a fine, as compared to imprisonment from one to 5 years in the current code, and in the wording of para.2, imprisonment from one month to one year or a fine, as compared to imprisonment from 6 months to 3 years in the current code.

The offence of family abandonment is provided for in Art. 305 of the Romanian Criminal Code and in Art. 378 of the the new Criminal Code. In terms of the objective side a few changes have occurred, namely: in para. 1, letter c, bad-faith failure to pay the alimony established in court for three months is an offence in the new regulation as compared to the current regulation in which the period is of only two months. Also, a new variant of committing this act is introduced by para. 2 , as "the bad-faith failure by the person convicted to provide regular benefits established by court order in favour of the persons entitled to maintenance from the victim of the offence". In terms of penalties, the new regulation provides for a single penalty; in the form of imprisonment from 6 months to 3 years or a fine. Thus, we notice that the minimum limit of 6 months is preserved and the maximum limit is increased from 2 years to 3 years in the variants of para. 1, letters a and $b$.

The offence of non-compliance with child custody measures, provided for in Art. 307 of the Romanian Criminal Code, respectively in Art. 379 of the new Romanian Criminal Code has the same legal content, including as regards the penalty. Thus, in terms of the objective side the act can be commited by a parent retaining his minor child in the wording of para. 1 or by any person entrusted with the minor through court order repeatedly preventing the parents from having personal contact with the minor, under the conditions established by the parties or by the competent body ${ }^{7}$.

In Art. 380 of the new Criminal Code the offence of obstructing access to the general compulsory education is provided for. According to para. 1 the penalty will be imprisonment from 3 months to one year or a fine for the act of the parent or the person entrusted by law with a minor who "unduly withdraws the minor or obstructs him/her by any means in attending general compulsory education".

Characteristics of the investigation of crimes against the family

In the case of the offence of bigamy, the circumstances under which the offence was committed should be determined. For this purpose, establishing the identity of the subjects of

\footnotetext{
${ }^{7}$ Regarding the right of the minor to have personal contact with the parent to whom he/she was not entrusted, and how to exercise it, see Andreea Drăghici, Andreea Tabacu, Amelia Singh, Relațiile minorului cu părinții şi familia extinsă. Aprecierea interesului superior al copilului. Criterii de apreciere (The Minor's Relationships with His/Her Parents and Extended Family. An Assessment of the Child's Best Interest. Criteria for the Assessment), EIRP conference, Danubius, Galați, conference proceedings, pp. 86-94.
} 
the crime, the number of participants and the capacity they have is required. In order to correctly classify the crime and make liable the persons involved the subjective side of the offence will be determined. Thus, the fact that both spouses knew they had a previous marriage or that only one of them had a different marriage will be demonstrated. Also, instigators or accomplices in the case may come forth, in which event information and data on the sequence of the participants' activities will be collected by researching the documents submitted at various institutions and by hearing persons having different capacities.

In order for the action of concluding a marriage/new marriage to constitute the material element of the offence of bigamy, on the one hand a personal connection between the first and second marriages has to be demonstrated, in the sense that one of the parties is identical in both marriages ${ }^{8}$ and on the other hand the validity of the first marriage has to be documented. To this end, the research bodies will request information from the Local Public Community Service of Personal Records or through collaboration with another service of the kind from the country or through international police cooperation.

In the case of family abandonment having a circumstantiated active subject, namely the person who has the obligation to ensure the maintenance of the victim, in the hearing of the persons special situations may arise during the interrogation, given the relationships between the subjects of the offence. For example, relationships between spouses, parents and children, grandparents and grandchildren, brothers and sisters, etc. Documentation will be gathered regarding the special cases in which the maintenance obligation rests upon several persons who will be held liable as co-authors.

To demonstrate the objective side of the offence, evidence will be provided regarding the offender's actions, for the purpose of demonstrating by any legally-permitted means whether: the person entitled to maintenance was abandoned, banished or left without any help; whether the victim was abandoned or banished from his/her dwelling. To this end, data will be collected from the crime scene, the dwelling or the area where the victim was abandoned, from witnesses, neighbours, people in the surroundings.

In the case of bad-faith failure to pay the maintenance obligation, the existence of bad faith will be proved, i.e. the perpetrator's means of livelihood will be determined, the changes in his/her state of health, the economic welfare of the family within which the offender lives, the expenses he/she incurs, be they justified or not, the periods during which he/she paid, the periods of interruption of payment. In order for the perpetrator to be held liable, the case documentation should reflect an omission, i.e. the author should have financial means, yet refuse to pay. When referring to a specific period of time, e.g. two months, evidence of the respective period should result from the statements of witnesses, of the persons deprived of the financial contribution or from the means of payment, etc.

The offence of ill treatment of the minor brings two directions to the investigation. One regards the activities specific to offences against the person, for example, where acts of physical violence were directed against the body of the living person (the material object of the crime). Another direction is the one investigating mental violence or actions that jeopardize the proper upbringing and education of the minor. In this case too, taking into account the passive subject - the minor - and the active subject circumstantiated by his/her capacity (mother and/or father) or the person entrusted with the minor's upbringing and education, there will be practical situations in which the minor's statements will be obtained with difficulty, because of their fear, trauma. The minor's hearing will be carried out under the rules of criminal tactics and the provisions of the Criminal Procedure Code, in compliance with the phases of the hearing.

\footnotetext{
${ }^{8}$ In this respect, see T.R. Popescu, Tratat de dreptul familiei (A Treatise on Family Law), vol. I, Bucharest, 1960, p. 280.
} 
Inside the family the child spends most of the time. Emerging personality of the child is severely influenced by the example of the parents 9 . The family is preparing the child for life, it can be an educational environment, or contrary, the conductor of behavioural deviations ${ }^{10}$.

The offence of ill treatment of a minor is a continuing offence, i.e. the actions/inactions applied are lasting, repeated and with negative consequences on the minor's proper development. The forensic investigation must prove, first of all, the fact that the measures and treatments to which the minor was subjected by the perpetrator resulted in a serious threat to the minor's development. Secondly, the investigation should clarify whether the perpetrator's action or inaction had a direct effect on the minor's bodily integrity and health $^{11}$. Forensic medical, psychiatric, traceological expertises a.s.o. will be presented.

In the case of the offence of breach of child custody orders, the degree to which the parent to whom the child was entrusted, or who had the right to have contact with the minor complied with the limitations arising from their legal obligations or from the conditions set by mutual agreement between the parties.

Thus, the hearing will include the persons involved, witnesses, participants in the case who can provide information regarding the programme, the activities they carry out together, the visiting schedule, the duration of the visit, the way they relate to one another.

Documentation will be gathered in a similar manner in cases where either the parent or the person to whom the minor was entrusted does not allow him/her, withdraws him/her or hinders him/her in attending the general compulsory education. In order to establish the circumstances in which the act was committed, data and information will be collected from the micro-social groups that the minor and the circumstantiated active subject attend. As a result, the investigation bodies will gather information from the management and/or teaching staff of the educational institutions about the minor's school attendance, participation in the extracurricular activities organized, their school performances, places they frequent, habits they have. The family environment will provide particulars of the participants, thus allowing the demonstration of the subjective side of the offence, hence the form of guilt of each person involved. Co-participation is possible and there may be instigators or accomplices involved in a case.

In addition to activities specific to forensic investigation, in all cases searches, reenactments, presentations for recognition may take place.

Of course, public interest does not only lie in identifying the perpetrator and individualizing the sentence, but also in the carrying out of activities of social reinsertion of offenders convicted for crimes of domestic violence.

Special care will be provided for the victim of a crime against the family, in terms of ensuring his/her counselling, assistance and protection.

As a general rule, the victim may apply for a protection order, in which case data will be collected with regard to the following issues: the relationship between the victim of domestic violence and the person against whom the restraining order is requested; establishing the circumstances in which the act was committed; details about the conditions of place, time and manner of committing the act; whether there were acts of domestic violence perpetrated on other members of the family; what people were present, especially whether they were minors; is there any risk for the minors; did the victim suffer any physical injury or

\footnotetext{
${ }^{9}$ Laura-Roxana Popoviciu, Răspunderea penală a minorului, Pro Universitaria Publishing House, Bucharest, 2012, p. 32.

${ }^{10}$ Idem.

${ }^{11}$ Carmina Aleca, Andreea Drăghici, Particularități ale cercetării infracțiunii de rele tratamente aplicabile minorului (Peculiarities of the Investigation of the Offence of Ill Treatment of a Minor), CKS e-books 2010, Pro Universitaria Publishing House, Bucharest, pp. 243-248.
} 
was he/she psychologically abused; did the victim receive medical care; does the victim have a forensic science certificate ${ }^{12}$.

Also, specialized central bodies of public administration, public local administration authorities, non-governmental organizations and other representatives of civil society will constantly take measures to prevent and combat domestic violence and the offences resulting from the application of abuse, of all forms of violence: verbal, psychological, physical, sexual, economic, social, and spiritual.

\section{Conclusions}

The complexity of the forensic investigation and the peculiarities of the activities carried out in order to establish the truth in a case, to demonstrate the constituent elements of offences which lie in the use of violence, are also due to the specificity of the relations between the participants.

The topicality of the subject presented is given by the fact that domestic violence occurs in all social and cultural backgrounds, in various ways, among people whose relationships are generally based on friendship, fondness, mutual moral and material support.

There are many situations where these facts go unnoticed, and, when they do get to be known by non-governmental organizations or institutions charged with their investigation, assistance or counselling, problems often occur in practice, because of the holding back and fears of the categories of people involved.

Public interest does not only lie in identifying the perpetrator and individualizing the sentence, but also in providing counselling, assistance and protection for the victims of the victims of crimes against family members, of domestic violence, in general.

Specialized central bodies of public administration, public local administration authorities, non-governmental organizations and other representatives of civil society will constantly take measures to prevent and combat domestic violence and the offences resulting from the application of abuse, of all forms of violence: verbal, psychological, physical, sexual, economic, social, and spiritual.

\section{Bibliography}

Nicoleta-Elena Buzatu, Illicit Consumption of Narcotics - Violence Generator, vol. MEDIMOND, International Proceedings Medimond - Monduzzi Editore International Proceedings, Division, Editografica Publishing House, Bologna, Italy, 2012;

Laura-Roxana Popoviciu, Răspunderea penală a minorului, Pro Universitaria Publishing House, Bucarest, 2012;

Nicoleta-Elena Buzatu, The Minor - The Active Subject of a Crime, vol. MEDIMOND, International Proceedings Medimond - Monduzzi Editore International Proceedings, Division, Publishing House Editografica, Bologna, Italy, 2012; For regulations concerning the minors in The New Penal Code, see Nicoleta-Elena Buzatu, Regulations Concerning the Minors as Stipulated in The New Penal Code, in Vol. „Criza actuală în contextul globalizării" ("The Current Crisis in the Context of Globalization"), ProUniversitaria Publishing House, Bucharest, 2010;

Viorica Banciu, Angela Jireghie, Delia Ştefania Florian, Multiculturalism and Metissage in the Globalization Context, Tudományos és kulturális folyóirat, published by Szent István Egyetem Gazdasági, Agrár- és Egészségtudományi Kar Békéscsaba, 2012. nr. 18, p. 80, gfk.tsf.hu/docs/system/files/files/pers2012_xvi_18.pdf

Carmina Aleca, Andreea Drăghici, Particularități ale cercetării infracțiunii de rele tratamente aplicabile minorului (Peculiarities of the Investigation of the Offence of Ill Treatment of a Minor), CKS e-books 2010, Pro Universitaria Publishing House, Bucharest;

\footnotetext{
${ }^{12}$ See Annex to Law No. 217/2003.
} 
Andreea Drăghici, Andreea Tabacu, Amelia Singh, Relațiile minorului cu părinții şi familia extinsă. Aprecierea interesului superior al copilului. Criterii de apreciere (The Minor's Relationships with His/Her Parents and Extended Family. An Assessment of the Child's Best Interest. Criteria for the Assessment), EIRP conference, Danubius, Galați, conference proceedings, 2010;

Nicolaie Iancu, Migrația internațională a forței de muncă (International Labour Migration), Pro Universitaria Publishing House, Bucharest, 2010;

Cornelia Rada, Repere antropologice ale familiei în contextul sănătății sexualreproductive (Anthropological Landmarks of the Family in the Context of Sexual and Reproductive Health), "Academiei Române" Publishing House, Bucharest, 2009;

Onica-Chipea, L., Aspecte socio-juridice privind protecția drepturilor copilului. Studiu de caz în județul Bihor (Socio-Legal Issues of Children's Rights Protection. A Case Study in Bihor County), Expert Publishing House, Bucharest, 2007;

T. R. Popescu, Tratat de dreptul familiei (A Treatise on Family Law), vol. I, Bucharest, 1960, 1960;

Law No. 217/2003 on preventing and combating domestic violence, republished in the Official Journal of Romania No. 365/2012;

The New Romanian Criminal Code, Law No. 286/2009 published in the Official Journal of Romania, Part I., No. 510/2009. 